\section{SOI: 1.1/TAS DOI: $10.15863 /$ TAS International Scientific Journal Theoretical \& Applied Science}

\author{
p-ISSN: 2308-4944 (print) e-ISSN: 2409-0085 (online) \\ Year: $2016 \quad$ Issue: $1 \quad$ Volume: 33 \\ Published: $30.01 .2016 \quad \underline{\text { http://T-Science.org }}$
}

\begin{abstract}
Rezvan Torabi
Assistance Professor in Islamic Azad University, Dehaghan Branch, Department of finance,

Esfahan, Iran torabi.economic@gmail.com
\end{abstract}

Fahimeh Ganji

Master of finance in Islamic Azad University, Dehaghan Branch, Department of finance,

Esfahan, Iran

SECTION 31. Economic research, finance, innovation, risk management.

\title{
A SURVEY OF THE RELATIONSHIP BETWEEN AGENCY COSTS AND FINANCIAL RATIOS IN COMPANIES LISTED ON TSE DURING 2008- 2012
}

\begin{abstract}
Economic growth, increased number of closely held companies and separation of management from ownership have challenged agency issues as one of the most important concenters of investors. Agency issues are based on the reality that investors have no required capability to manage the company affairs. Thus, this responsibility is delegated to managers. If managers and investors maximize their personal benefits and controlling the performance of agent requires costs. This shows that the agent attempts not to fulfill the benefits of owner and maximize his wealth. Additionally, selection of a good criterion to be sure of achieving final goal as maximizing the wealth of owners is one of the most important solutions of shareholders to evaluate the company performance and correct economic decisions. The present study evaluates the relationship between agency cost and financial ratios in companies listed on TSE. The agency relationship is a type of contract by which the owner delegates an agent to perform operation and delegate's power to take decision. By formation of agency relationship, agency costs of benefits conflict are created between parties. To measure financial ratios via profitability ratios, six criteria of ROA-ROS-ROE-NPM-ROC-GPM are applied. To do this, the information of companies listed on TSE during 20082012 is used. The general results of study show that there is a significant association between agency costs, financial ratios, return on asset, return on sale, net profit margin, return on capital and gross profit margin and all hypotheses are supported.

Key words: Agency theory, Financial ratios, Agency costs, Benefits conflict, Profitability ratios, Stock exchange market.

Language: English

Citation: Torabi R, Ganji F (2016) A SURVEY OF THE RELATIONSHIP BETWEEN AGENCY COSTS AND FINANCIAL RATIOS IN COMPANIES LISTED ON TSE DURING 2008-2012. ISJ Theoretical \& Applied Science, 01 (33): 18-21.

Soi: http://s-o-i.org/1.1/TAS-01-33-4 Doi: crossef http://dx.doi.org/10.15863/TAS.2016.01.33.4
\end{abstract}

\section{1- Introduction}

Agency problem is encouraging the agent to take decisions to maximize the welfare of owner (owners). By formation of agency relationship, by benefits conflict between two parties, agency cost is increased. The managers of companies are agents of shareholders. This relationship is full of contradictory benefits. Agency theory as the analyzer of these conflicts is an important part of economic and financial literature. One of the tools to determine the financial situation of companies is analysis of financial ratios. Indeed, financial ratios reveal important realities regarding the financial condition and operation of a company. The ratios evaluate the relationship between some variables and this evaluation provides an attitude to different aspects of business units as profitability, liquidity, capacity adequacy, quality of asset and management risk. Determination of required ratios depends upon the purpose of analysis (e.g. profitability, liquidity, etc.). Due to easy calculation and easy understanding, proportional evaluation has wide application. The analysis of financial statements is started with using financial ratios based on balance sheet data, profit and loss statement and cash flow statement. Financial ratios show the power or weakness of companies compared to other companies of the same industry, pioneer companies of the past year performance of the same company. The main problem of study is the evaluation of the relationship between agency costs and financial ratios in the companies listed on TSE. It is attempted to answer this question whether there 


\begin{tabular}{l|lrl|l|ll} 
& ISRA (India) & $=\mathbf{1 . 3 4 4}$ & SIS (USA) & $=\mathbf{0 . 9 1 2}$ & ICV (Poland) & $=\mathbf{6 . 6 3 0}$ \\
Impact Factor: & ISI (Dubai, UAE) $=\mathbf{0 . 8 2 9}$ & PUHIL (Russia) $=\mathbf{0 . 1 7 9}$ & PIF (India) & $=\mathbf{1 . 9 4 0}$ \\
& GIF (Australia) & $\mathbf{0 . 5 6 4}$ & ESJI (KZ) & $=\mathbf{1 . 0 4 2}$ & & \\
& JIF & $=\mathbf{1 . 5 0 0}$ & SJIF (Morocco) $=\mathbf{2 . 0 3 1}$ & &
\end{tabular}

is a significant relationship between agency costs with financial ratios in companies listed on TSE or not. If it is, this relationship can be changed.

\section{2- Review of Literature}

Noravesh and Ebrahimi Kordlar (2011) in a study evaluated the role of institutional investment in reduction of liquidity in TSE. The findings of study showed that in companies with high institutional degree compared to low institutional ownership, the future profit information is reflected mostly in stock price.

Mojtahedzade (2011) evaluates the relationship between ownership as an independent variable and agency costs, independent audit costs and managers fee as dependent variable. The results of study showed that there was no relationship between management ownership and agency costs, independent audit cost and managers fee.

Mehdi and Monfared (2011) in a study evaluated the effect of board composition on agency costs from executive theory and found that the executive members of board had no significant effect on agency costs.

Lontis et al., (2011) considered audit cost of companies as agency cost and evaluated the relationship between product market competition and agency costs in Greece. They found that audit hours and audit cost had inverse and significant association with product market competitiveness.

Wang (2010) performed empirical test of the relationship between free cash flow and agency cost and then evaluated the effect of both of them on performance of Taiwan companies. Considering total asset turnover and operating expense ratio as sufficient agency cost measures, the study found evidence to support the agency theory, meaning AC had a significantly negative impact on firm performance and stock return. In contrast, the study found a significantly positive relation between fee cash flow and firm performance measures, indicating lack of evidence supporting the free cash flow hypothesis.

\section{3- Study variables Financial ratios}

There are various classifications of financial ratios, a general division as applied more than other classifications is the classification of financial ratios in five groups as:

1- Liquidity ratios

2- Return ratios

3- Performance ratios

4- Profitability ratios

5- Market ratios

Based on the number of extracted financial ratios of financial reports, we should consider the internal correlation and overlapping between financial ratios. The ratios with the lowest internal correlation should be in a group to apply them as descriptive variables of an event.

In each classification, by factor analysis, financial ratios are selected and besides the relevant changes with return on stock rate have the lowest internal correlation with each other. The selected ratios in the study are mentioned in the following Table.

Table 1

Applied financial ratios.

\begin{tabular}{|c|c|}
\hline Ratio type & Classification \\
\hline Current ratio & \multirow[t]{2}{*}{ Liquidity ratios } \\
\hline Quick ratio & \\
\hline GPM & \multirow[t]{2}{*}{ Profitability ratios } \\
\hline Sale to profit & \\
\hline Inventory turnover & \multirow[t]{2}{*}{ Performance ratios } \\
\hline Fixed assets turnover & \\
\hline $\mathrm{ROA}$ & \multirow[t]{2}{*}{ Return ratios } \\
\hline Worth return on asset & \\
\hline Earnings per share & \multirow[t]{2}{*}{ Market ratios } \\
\hline Price to income & \\
\hline
\end{tabular}

\section{4- Analysis results}

The findings of main hypothesis test show that there is a significant association between agency costs and financial ratios. 


\begin{tabular}{|c|c|c|c|c|c|c|}
\hline Impact Factor: & $\begin{array}{l}\text { ISRA (India) } \\
\text { ISI (Dubai, UAE } \\
\text { GIF (Australia) } \\
\text { JIF }\end{array}$ & $\begin{array}{l}=1.344 \\
=0.829 \\
=0.564 \\
=1.500\end{array}$ & $\begin{array}{l}\text { SIS (USA) } \\
\text { PИНЦ (Russia) } \\
\text { ESJI (KZ) } \\
\text { SJIF (Morocco) }\end{array}$ & $\begin{array}{l}=0.912 \\
=0.179 \\
=1.042 \\
=2.031\end{array}$ & $\begin{array}{l}\text { ICV (Poland) } \\
\text { PIF (India) }\end{array}$ & $\begin{array}{l}=6.630 \\
=1.940\end{array}$ \\
\hline
\end{tabular}

Statistics data.

Table 2

\begin{tabular}{|c|c|c|c|c|c|c|c|c|c|}
\hline $\begin{array}{l}\text { DW } \\
\text { statistics }\end{array}$ & $\begin{array}{l}\text { Statistics } \\
\text { F }\end{array}$ & $\bar{R}^{2}$ & 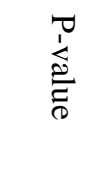 & 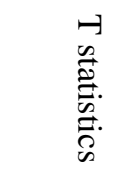 & 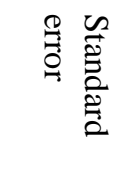 & 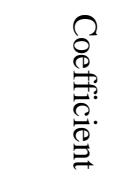 & 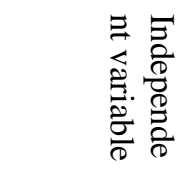 & 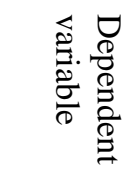 & 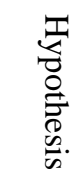 \\
\hline \multirow[t]{3}{*}{1.7} & \multirow[t]{3}{*}{1227} & \multirow[t]{3}{*}{0.99} & 0.00 & 636.49 & 0.00 & 0.579 & $\mathrm{C}$ & \multirow[t]{3}{*}{$\log r_{t}$} & \multirow[t]{3}{*}{1} \\
\hline & & & 0.00 & 58.354 & 0.01 & 0.743 & $\log \left(a_{t-1}\right)^{2}$ & & \\
\hline & & & 0.00 & 23.883- & 0.013 & $0.313-$ & $\log \left(b_{t-1}\right)^{2}$ & & \\
\hline \multirow[t]{2}{*}{1.551} & \multirow[t]{2}{*}{157.7} & \multirow[t]{2}{*}{0.34} & 0.00 & 10.248 & 0.122 & 1.254 & $\log d_{t-1}$ & \multirow[t]{2}{*}{$\log r_{t}$} & \multirow[t]{2}{*}{2} \\
\hline & & & 0.00 & 19.152 & 0.233 & 4.465 & $\log \mathrm{e}_{\mathrm{t}-1}$ & & \\
\hline \multirow[t]{3}{*}{1.894} & \multirow[t]{3}{*}{28.08} & \multirow[t]{3}{*}{0.15} & 0.00 & 5.9874 & 0.249 & 1.496 & $\mathrm{C}$ & \multirow[t]{3}{*}{$\log r_{t}$} & \multirow[t]{3}{*}{3} \\
\hline & & & 0.00 & 4.0898 & 0.050 & 0.205 & $\log \left(f_{t-1}\right)^{2}$ & & \\
\hline & & & 0.00 & $7.0780-$ & 0.277 & $1.966-$ & $\log \left(J_{t-1}\right)^{2}$ & & \\
\hline \multirow[t]{2}{*}{1.632} & \multirow[t]{2}{*}{1974} & \multirow[t]{2}{*}{0.93} & 0.00 & 95.721- & 0.000 & $0.065-$ & $\log h_{t-1}$ & \multirow[t]{2}{*}{$\log r_{t}$} & \multirow[t]{2}{*}{4} \\
\hline & & & 0.00 & 565.15 & 0.000 & 0.299 & $\log k_{t-1}$ & & \\
\hline \multirow[t]{2}{*}{1.457} & \multirow[t]{2}{*}{3784} & \multirow[t]{2}{*}{0.95} & 0.00 & 11.052 & 0.000 & 0.003 & $\log p_{t-1}$ & \multirow[t]{2}{*}{$\log r_{t}$} & \multirow[t]{2}{*}{5} \\
\hline & & & 0.00 & 16.099 & 0.000 & 0.0001 & Log $\mathrm{s}_{\mathrm{t}-1}$ & & \\
\hline \multirow[t]{2}{*}{1.522} & \multirow[t]{2}{*}{2893} & \multirow[t]{2}{*}{$95 . /$} & 0.00 & 95.721- & 0.000 & $0.065-$ & $\log h_{t-1}$ & \multirow[t]{2}{*}{$\log r_{t}$} & \multirow[t]{2}{*}{6} \\
\hline & & & 0.00 & 565.15 & 0.000 & 0.299 & $\log k_{t-1}$ & & \\
\hline \multirow[t]{2}{*}{1.362} & \multirow[t]{2}{*}{1435} & \multirow[t]{2}{*}{0.95} & 0.00 & 11.052 & 0.000 & 0.003 & $\log p_{t-1}$ & \multirow[t]{2}{*}{$\log r_{t}$} & \multirow[t]{2}{*}{7} \\
\hline & & & 0.00 & 16.099 & 0.000 & 0.0001 & $\log _{\mathrm{S}_{\mathrm{t}-1}}$ & & \\
\hline
\end{tabular}

As shown in the Table, P-value in all hypotheses is 0.000 and the statistics in third hypothesis is more than other hypotheses.

The results show that there is a linear significant association between agency costs and return on asset of company with their ratios. Also, the results show that there is a linear significant association between return on sale of company in studied companies with their agency cost.

The results show that there is a linear significant association between return on equity in studied companies with their residual earnings and there is a linear significant association between net profit return with agency cost in studied companies. Also, there is a linear significant association between agency costs and gross profit of company in studied companies. The results show that there is a linear significant association between sale return of company in the studied companies with their agency cost.

\section{5- Conclusion and Recommendation}

As shown in the results of study hypotheses, there are various factors affecting agency costs and if they are identified well by organizations can be used and can improve operation of company and by reduction of agency costs, benefits of two groups are consistent and there is a little benefits conflict and by reduction of company costs, shareholders can achieve maximum benefits and wealth. Managers are inclined to company growth more than its optimal amount as the company growth leads to the increase of benefits under the control of managers, increase of power and reward. Based on the results of study, the following recommendations are presented:

ISPC Perspectives in science for 2016 , 


\begin{tabular}{|c|c|c|c|c|c|c|}
\hline Impact Factor: & $\begin{array}{l}\text { ISRA (India) } \\
\text { ISI (Dubai, UAF } \\
\text { GIF (Australia) } \\
\text { JIF }\end{array}$ & $\begin{array}{l}=1.344 \\
=0.829 \\
=0.564 \\
=1.500\end{array}$ & $\begin{array}{l}\text { SIS (USA) } \\
\text { PИНЦ (Russia) } \\
\text { ESJI (KZ) } \\
\text { SJIF (Morocco) }\end{array}$ & $\begin{array}{l}=0.912 \\
=0.179 \\
=1.042 \\
=2.031\end{array}$ & $\begin{array}{l}\text { ICV (Poland) } \\
\text { PIF (India) }\end{array}$ & $\begin{array}{l}=6.630 \\
=1.940\end{array}$ \\
\hline
\end{tabular}

1- Based on the results of study, it is recommended that the companies consider return on sale of companies mostly. To reduce agency cost due to its inverse relationship with return on sale, its sale is increased.

2- To evaluate the relation of financial ratios and agency costs, capital pricing model
(CAPM) is applied and the results are compared with data combination model.

3- We can use neural network model and logit regression technique to predict return on stock. For results reliability, the study is conducted in long period as 10 years. The number of financial ratios is increased or other relevant ratios are applied.

\section{References:}

1. Ang J, cok R, Lin J (2000) Agency costs and ownership Structure. The Journal of finance, Vol.55 no, 1, pp.81-106.

2. Bathala CT, Moon KP, Rao RP (1994) "Managerial ownership, debt policy and the impact of institutional holdings: An agency perspective", Financial management, 23:38-50.

3. Chung R, firth M, kim $\mathrm{T}$ (2005) "Earning management, Surplus free cash flow, and external monitoring", Journal of Business Research, 58:76.

4. Chen JCH, Parker LJ, Lin B (2006) Techno premiership in native American Businesses: Current issues and Future with a case study, International Journal of management and Enterprise Development.3(1-2):1084.

5. Doukas JA, Mcknight PJ, Pantzalisc (2005) "Security analysis costs and uk firm characteristics "International Review of financial Analysis, vol.14, pp.493-507.

6. Fleming GR Heaney, Mccker R (2005) "Agency costs and ownership structure in Australia".pacific-Basin finance Journal, vol.13. pp.29-59.

7. Florackis C (2008) "Agency costs and corporate governance mechanisms: Evidence for $\mathrm{VK}$ firms" International journal of managerial finance, vol.4, pp37-59.

8. Jensen MC, Meckling W (1976) "Theory of the firm: managerial behavior, agency costs and ownership structure" Journal of Financial Economics, Vol. 3, pp. 305-360.

9. Mcknight F, Weir C (2008) "Agency costs, corporate governance mechanisms and ownership structure in large UK publicly quoted companies: A panel data analysis" The Quarterly Review of Economics and Finance.Vol.49 (2), pp.139-158.

10. Mcconnell J, Servaes H (1990) Additional evidence on equity ownership and corporate values, Journal of financial economics, 27:59.

11. Wang GY (2010) The Impacts of free cash flows and Agency costs on firm performance, Journal of service science \& mangment.No.3, pp.408-418.

12. Singh M, Davidson WA (2003) “Agency costs, ownership structures and corporate governance mechanisms" Journal of Banking and Finance, Vol. 27, pp. 793-816. 